\title{
Comparative evaluation of physical parameters of salted goat and sheep meat blankets "mantas" from Northeastern Portugal
}

\author{
A. Ortega ${ }^{1} \cdot$ D. Chito $^{2} \cdot$ A. Teixeira ${ }^{1,3}$
}

Received: 14 March 2015/Accepted: 23 May 2016/Published online: 27 May 2016

(C) Springer Science+Business Media New York 2016

\begin{abstract}
Physical properties and color parameters were compared in goat and sheep meat blankets "mantas" obtained after salting and air-drying processes at $8-10{ }^{\circ} \mathrm{C}$ for 48 and $120 \mathrm{~h}$, respectively. Animal which were used in preparation process did not meet the requirement of age and weight to be involved into the classifications of Protected Designation of Origin or Geographical Indication established by Portuguese regulations. $\mathrm{pH}$, water activity $\left(\mathrm{a}_{\mathrm{w}}\right)$, water holding capacity (WHC) and texture were assessed in longissimus dorsi muscle of fresh meat samples. The processes of product fabrication consisted of six stages: ageing, deboning and obtaining of mantas, salting, stumbling, washing, air drying and vacuum packaging. Color CIELAB parameters were monitored during salting and air-drying processes at subscapularis and semimembranosus muscles. Significant differences were found between physical characteristics of fresh meats; texture and WHC were the factors most influenced by ageing. Sheep meat blankets reached values of $\mathrm{L}^{*}, \mathrm{~b}^{*}$ and $\mathrm{C}^{*}$ higher than the goat but a lower value of $\mathrm{a}^{*}$.
\end{abstract}

A. Ortega

raortega@ipb.pt

1 Escuela Superior Agraria, Instituto Politécnico de Bragança, Campus de Santa Apolónia, 5300-253 Bragança, Portugal

2 Edificio de los laboratorios, Departamento de Química, Facultad de Ciencias Naturales Exactas y de la Educación, Universidad del Cauca, Sector Tulcán, 190003 Popayán, Colombia

3 CECAV, Animal and Veterinary Research Centre, Universidade Trás-os-Montes e Alto Douro, Vila Real, Portugal
Keywords Small ruminants $\cdot$ Meat quality $\cdot$ Salted meat

\section{Introduction}

Production of goats and sheep still plays an important role in the economy of Portugal with an annual contribution average of 23.000 tonnes [1]. Sheep and goat meat are within the three species most consumed at national level [2]. Serrana and Churra Galega Bragançana are the most important Portuguese goat and sheep breeds. Their breeding, production and commercialization of derived products have been promoted as viable strategies for development of rural economy. Meat from these small ruminants provides to consumers especial characteristics such as low-fat content, high protein content and acceptable organoleptic features [3-5].

Portugal government adopted the European requirements to regulate the Protected Designation of Origin and Geographical Indication in order to encourage and value agricultural and foodstuffs products as well as to safeguard the authenticity of the models of extensive farming performed in disadvantaged regions. This fact has contributed to devalue meat from heavier and older animals as well as culled goats and sheep. In this sense, new strategies for recovering these species are needed. Cured meat products appear as a reasonable alternative due to they combine a high protein content with proper lipid composition to obtain a food widely accepted by consumers. Such products are the result of having submitted the meat to treatments with salt or smoke and drying process [6, 7]. Among food produced with meat of species such as goats, sheep, deer and horses are: Cecina in Spain, biltong in South Africa, jerky in South America and bresaola in Italy $[6,8-11]$. 
In this context, a project among a research center, two breeder associations and a meat manufacturing industry was developed to add value to a product, meat blankets "mantas", using goat and sheep meat from culled animals with very low commercial value and consumer acceptability that cannot be commercialized as Protected Origin Denomination (DOP) or Protected Geographical Indication (PGI). The aim of this work was to characterize the physical characteristics during the main stages of fabrication process (fresh, salted and air-dried meat) and to study the effect of each species and muscle sampled on physical characteristics.

\section{Materials and methods}

\section{Animals and raw material}

Sixteen culled animals, eight Serrana goats and eight Churra Galega Bragançana ewes between 8 and 12 years old and with an average of $45 \pm 5 \mathrm{~kg}$ overweight were randomly selected from several flocks by goat and sheep Portuguese breeder Associations (ANCRAS and ACOB). All animals were raised under the same production system based on daily natural grassland and free-feeding wheat or rye straw. Animals were slaughtered in official local abattoir of Bragança.

\section{Meat processing}

After slaughter, the average carcass weight was $20.0 \pm 1.9 \mathrm{~kg}$. Meat processing involved the following steps: (1) Ageing: carcasses were cooled at $4{ }^{\circ} \mathrm{C}$ for a period of 4 days in dark; (2) Blankets obtention (mantas) of meat: carcasses were divided into quarters by a straight cut from a point close to the lower edge of the backbone at the 13th rib and then, deboned separating only the long bones and vertebral column, retaining the ribs in the anterior quarter and preventing muscles from being separated; (3) Salting (using $\mathrm{NaCl} 20 \% \mathrm{w} / \mathrm{w}$ ) and staking mantas pieces (eight per species) into piles-each one from the others were separated by a $5 \mathrm{~cm}$ of coarse marine salt during $96 \mathrm{~h}$ in a cooler with a constant temperature of $48{ }^{\circ} \mathrm{C}$ and relative humidity of $75 \%$; (4) Stumbling: mantas were rearranged every $12 \mathrm{~h}$ moving down the upper-most piles in order to homogenize the salt distribution; (5) Washing or brushing to remove the excess of salt; (6) Air-drying at $8-10{ }^{\circ} \mathrm{C}$ during $48 \mathrm{~h}$ and a relative humidity of 60-70\%; (7) Vacuum packaging and refrigeration. Meat samples were taken from the longissimus dorsi, subscapularis and semimembranosus muscles for instrumental analysis.

\section{Measurements and instruments}

One hour after post mortem $\mathrm{pH}$ and $\mathrm{a}_{\mathrm{w}}$ measurements were recorded from the longissimus dorsi muscle between the 12th and 13th ribs of the left side of carcass. After slaughter and over ageing, $\mathrm{pH}$ and $\mathrm{a}_{\mathrm{w}}$ were measured again in subscapularis and semimembranosus muscles using a portable pH meter HANNA HI 99163 with pre-amplified pH electrode FC 232D and removable stainless steel blade according to the Portuguese standard [12]; water activity measurements were performed with a probe measuring over the range $0-1$, with room temperature control using a water activity probe (HygroPalmAw1 rotronic 8303, Bassersdorf, Switzerland) according to [13]. At the end of refrigeration time, water-holding capacity (WHC) was evaluated according to the Honikel procedure [14], as well as, shear force (SF). This measurement consisted of meat samples placed inside a bag into a water bath heated at $70{ }^{\circ} \mathrm{C}$. After cooled, the muscle was cut (the cut line parallel to the muscle fibres direction) in pieces of about $2 \mathrm{~cm}$ long and $1 \mathrm{~cm}^{2}$ section, and measured (8 repetitions for sample) with the maximum SF in kgf with an Instron press (5543 J-3177) equipped with a Warner-Bratzler cell. The coordinates of color of CIELAB lightness $\left(\mathrm{L}^{*}\right)$, redness $\left(a^{*}\right)$ and yellowness $\left(b^{*}\right)$ were assessed in fresh meat samples in longissimus dorsi, while in salting and air-dried samples in subscapularis and semimembranosus muscles using a chromameter Minolta CR 10 according to [15]. Hue $\left(\mathrm{H}^{*}\right)$ and Chroma $\left(\mathrm{C}^{*}\right)$ attributes were calculated using $\mathrm{a}^{*}$ and $b^{*}$ coordinates. All measurements were performed by triplicate.

\section{Statistical analysis}

The experimental design was completely randomized. The effects of species and muscle location on color attributes were studied. The effects of specie and ageing on $\mathrm{pH}, \mathrm{a}_{\mathrm{w}}$, WHC and texture were analyzed. Data were analyzed by ANOVA with ageing, species or muscle location as fixed effects. The least square means were calculated and the Tukey test was used to determine significant differences. All statistical differences were considered significant at a level of $\mathrm{P}<0.05$. Statistical analysis was performed using the SPSS software for Windows, version 19.

\section{Results and discussion}

\section{Determination of fresh meat parameters}

Physical characteristics of fresh goat and sheep meat are gathered in Table 1. The marked decline of $\mathrm{pH}$ in meat from both species between 1 and $24 \mathrm{~h}$ puts in evidence the 
Table 1 Ageing effect on fresh goat and sheep meat physical characteristics

\begin{tabular}{lrrrl}
\hline Physical parameters & Time & \multicolumn{2}{l}{ Effect of ageing } & \multirow{2}{*}{ Significance } \\
\cline { 3 - 4 } & & \multicolumn{1}{l}{ Goat } & \multicolumn{1}{l}{ Sheep } \\
\hline $\mathrm{pH}(\mathrm{n}=48)$ & $1 \mathrm{~h}$ & $6.60 \pm 0.23$ & $6.71 \pm 0.24$ & $* * *$ \\
& $24 \mathrm{~h}$ & $6.00 \pm 0.35$ & $5.85 \pm 0.31$ & $* * *$ \\
$\mathrm{a}_{\mathrm{w}}(\mathrm{n}=48)$ & $1 \mathrm{~h}$ & $0.94 \pm 0.02$ & $0.94 \pm 0.17$ & $\mathrm{NS}$ \\
& $24 \mathrm{~h}$ & $0.93 \pm 0.01$ & $0.96 \pm 0.02$ & $* * *$ \\
& $48 \mathrm{~h}$ & $0.92 \pm 0.01$ & $0.90 \pm 0.27$ & $* * *$ \\
& $96 \mathrm{~h}$ & $0.92 \pm 0.18$ & $0.89 \pm 0.03$ & $* * *$ \\
WHC $(\mathrm{n}=48)(\mathrm{g} \mathrm{water})$ & $24 \mathrm{~h}$ & $17.86 \pm 6.58$ & $25.08 \pm 6.06$ & $* * *$ \\
Texture $(\mathrm{n}=64)\left(\mathrm{kgf} / \mathrm{cm}^{2}\right)$ & $24 \mathrm{~h}$ & $7.89 \pm 1.85$ & $5.85 \pm 1.70$ & $* * *$ \\
\hline Resuls correspond
\end{tabular}

Results correspond to the mean \pm standard deviation

$N S$ not significant

$* * * \mathrm{P} \leq 0.001$ loss of strength and permeability of the cell membrane [16] and it is a result of the post-mortem acidification and rigor development. Significant differences $(\mathrm{P} \leq 0.001)$ were found between the average $\mathrm{pH}$ of fresh meat of goat and sheep during ageing. These findings evidence rapid changes of large structural proteins which tend to take place within $48 \mathrm{~h}$ post mortem. In addition, this behavior could be associated to the level of degradation of myofibrillar proteins during refrigeration storage [17]. The mean $\mathrm{pH}$ value of goat meat after $1 \mathrm{~h}$ of cooling (6.60) was comparable to the value reported by [18] for French goat meat $(6.27 \pm 0.45)$. Ultimate $\mathrm{pH}$ measured after $24 \mathrm{~h}$ of slaughter animals was significantly $(\mathrm{P} \leq 0.001)$ higher in goat meat than sheep.

Significant differences $(\mathrm{P} \leq 0.001)$ between species were found except for $\mathrm{a}_{\mathrm{w}}$ determined at $1 \mathrm{~h}$ after ageing. Sheep meat showed a value of $a_{w}$ significantly higher than goat meat at $24 \mathrm{~h}$. This difference could be a result of different carcass fat level, which is lower in goat than sheep carcasses. After $24 \mathrm{~h}$ of cooling, $\mathrm{a}_{\mathrm{w}}$ of carcasses of both species dropped in accordance with the results found and described previously by [19].

Water holding capacity is due to the immobilization of surface water on myofibrils systems. It is mainly determined by the characteristics of species [20]. During early post mortem $(24 \mathrm{~h})$, the mean value of WHC for sheep meat was significantly higher $(\mathrm{P} \leq 0.001)$ than goat meat as it was been expected since the fat level in goat meat is lower than sheep meat, affecting consequently WHC. On the other hand, the effect of $\mathrm{pH}$ and storage time on the myofibrillar component of muscle is well recognized $[7,16]$. Thus, the higher WHC in sheep meat should be associated to the depletion less pronounced of $\mathrm{pH}$ ( 1 to $24 \mathrm{~h}$ ) leading to a lower denaturalization process of myofibrillar, but behavior observed is opposed. WHC results suggest that other factors such as genetic origin, enzymes content and transportation of meat [21] should be influencing the observed behavior.

Regarding texture, goat meat presented a value statistically significant $(\mathrm{P} \leq 0.001)$ higher than sheep fresh meat. This parameter involves properties such as tenderness and juiciness which are also affected by aspects such as chemical composition, the intrinsic enzyme activity or $\mathrm{pH}$ of meat [20]. Several studies have reported that goat meat has thicker muscle fibers [22] due to higher collagen content and less intramuscular fat than sheep [23]. In addition, the higher denaturalization process in sheep meat ( $\mathrm{pH}$ 5.85) contributes to its higher tenderness $\left(5.85 \mathrm{kgf} / \mathrm{cm}^{2}\right)$. Water activity and WHC values are in agreement with texture values found in this study. Goat meat differed in $17 \%$ from determined by [6] after $120 \mathrm{~h}$ cooling $\left(6.9 \mathrm{kgf} / \mathrm{cm}^{2}\right)$.

Data presented in Table 2 show the color parameters of fresh meats. $a^{*}, b^{*}, L^{*}$ and the Chroma $\left(C^{*}\right)$ measurements in sheep meat were significantly higher than goat meat while $\mathrm{H}^{*}$ parameter was significantly $(\mathrm{P} \leq 0.05)$ lower in sheep meat than goat.

The goat carcasses had a mean $\mathrm{L}^{*}$ value reasonably consistent with values reported by [6] for samples from similar species at two different ageing periods (33.0, 32.3 for 72 and $120 \mathrm{~h}$ of ageing, respectively); $\mathrm{H}^{*}, \mathrm{a}^{*}$ and $\mathrm{b}^{*}$ parameters were below and $\mathrm{C}^{*}$ attribute showed differences over $50 \%$. The findings could be explained from a faster denaturation of protein portion of myoglobin in this study, which would accelerate the oxidation of iron and, therefore, causes a value higher of $a^{*}$.

Color parameters were affected by sampling area or type of muscle. Significantly higher values of $\mathrm{L}^{*}, \mathrm{H}^{*}, \mathrm{a}^{*}$ and $\mathrm{C}^{*}$ were detected in subscapularis muscles than in semimembranosus. Intrinsic factors would be influencing these parameters such as rigor mortis development in muscle, muscle features and animal stress reactivity [24]. It is known that the variability of color parameters due to type 
Table 2 Effects of species and sampling area on fresh goat and sheep meat color parameters

\begin{tabular}{llllll}
\hline & $\mathrm{L}^{*}$ & $\mathrm{a}^{*}$ & $\mathrm{~b}$ & $\mathrm{H}$ & $\mathrm{C}$ \\
\hline Species & & & & & \\
$\quad$ Goat & $34.12 \pm 2.43$ & $19.45 \pm 3.01$ & $10.54 \pm 5.23$ & $28.07 \pm 4.81$ & $22.28 \pm 5.42$ \\
$\quad$ Sheep & $34.57 \pm 3.47$ & $21.53 \pm 2.74$ & $10.69 \pm 1.76$ & $26.42 \pm 3.39$ & $24.07 \pm 2.94$ \\
Sampling area & & & & & \\
$\quad$ Subscapularis & $34.97 \pm 2.55$ & $21.15 \pm 3.12$ & $11.01 \pm 1.92$ & $27.55 \pm 3.82$ & $23.89 \pm 3.34$ \\
$\quad$ Semimembranosus & $33.71 \pm 3.14$ & $19.83 \pm 2.90$ & $10.23 \pm 5.53$ & $26.93 \pm 4.81$ & $22.47 \pm 5.57$ \\
Effects & & & & & $*$ \\
$\quad$ Species & $* * *$ & $* * *$ & $* *$ & $*$ & $* *$ \\
$\quad$ Sampling area & $*$ & $* * *$ & $\mathrm{NS}$ & $* * *$ & $*$ \\
S $\times$ SA & NS & $*$ & $*$ & NS & \\
\hline
\end{tabular}

Results correspond to the mean \pm standard deviation

NS not significant

$* \mathrm{P} \leq 0.05 ; * * \mathrm{P} \leq 0.01 ; * * * \mathrm{P} \leq 0.001$
Table 3 Salting effect on goat and sheep meat physical characteristics

\begin{tabular}{|c|c|c|c|}
\hline \multirow{2}{*}{$\begin{array}{l}\text { Physical } \\
\text { parameters } \\
\text { Time }\end{array}$} & \multicolumn{2}{|l|}{ Effect of salting } & \multirow[t]{2}{*}{ Significance } \\
\hline & Goat $(n=48)$ & Sheep $(n=48)$ & \\
\hline \multicolumn{4}{|l|}{$\mathrm{pH}$} \\
\hline $24 \mathrm{~h}$ & $5.84 \pm 0.22$ & $5.74 \pm 0.13$ & $* * *$ \\
\hline \multicolumn{4}{|l|}{$\mathrm{a}_{\mathrm{w}}$} \\
\hline $24 \mathrm{~h}$ & $0.89 \pm 0.02$ & $0.90 \pm 0.01$ & NS \\
\hline
\end{tabular}

Results correspond to the mean \pm standard deviation

$N S$ not significant

$* * * \mathrm{P} \leq 0.001$

of muscles is important and mainly explained from different type of metabolism, $\mathrm{pH} /$ temperature regimes, rate of oxidation and respiratory activity [25]. A significant $(\mathrm{P} \leq 0.05)$ interaction between species and sampling area was observed for $\mathrm{a}^{*}, \mathrm{~b}^{*}$ and $\mathrm{C}^{*}$ parameters, meaning that meat samples taken from different muscles in goats and sheep behaved differently on redness, yellowness and Chroma.

\section{Determination of salted and dried meat parameters}

Determinations of $\mathrm{pH}$ and $\mathrm{a}_{\mathrm{w}}$ in salted meat samples are shown in Table 3. Significant differences between species were found for $\mathrm{pH}$ but not for $\mathrm{a}_{\mathrm{w}}$. Such differences should be involving different influence on the tenderness meat of two species. The loss of $\mathrm{a}_{\mathrm{w}}$ that takes place during salting process due to the reduction of humidity was encouraged by the acidification and proteins denaturation. Both meat samples showed a similar progressive decrease.

Table 4 shows the color parameters assayed in salted samples. Results follow the typical evolution observed in meat samples storage under similar conditions [6, 26, 27]. A noteworthy change of $a^{*}$ respect to fresh meat was
Table 4 Effects of species and sampling area on goat and sheep meat color parameters after salting process

\begin{tabular}{llllll}
\hline & $\mathrm{L}^{*}$ & $\mathrm{a}^{*}$ & $\mathrm{~b}^{*}$ & $\mathrm{H}$ & $\mathrm{H}^{*}$ \\
\hline Species & & & & & \\
$\quad$ Goat & $30.56 \pm 3.15$ & $10.72 \pm 5.23$ & $6.87 \pm 1.99$ & $35.51 \pm 12.94$ & $13.05 \pm 4.81$ \\
$\quad$ Sheep & $31.18 \pm 18.55$ & $8.91 \pm 4.01$ & $7.02 \pm 2.52$ & $39.67 \pm 11.13$ & $11.59 \pm 4.11$ \\
Sampling area & & & & & \\
$\quad$ Subscapularis & $31.68 \pm 3.24$ & $11.38 \pm 5.15$ & $7.61 \pm 2.44$ & $36.15 \pm 12.76$ & $14.02 \pm 4.81$ \\
$\quad$ Semimembranosus & $30.07 \pm 19.14$ & $8.25 \pm 3.60$ & $6.29 \pm 1.91$ & $39.02 \pm 11.40$ & $10.61 \pm 3.42$ \\
Effects & & & & & $* *$ \\
$\quad$ Species & $\mathrm{NS}$ & $* * *$ & $* * *$ & $* *$ & $* *$ \\
$\quad$ Sampling area & $\mathrm{NS}$ & $* * *$ & $\mathrm{NS}$ & $* * *$ & $\mathrm{NS}$ \\
S $\times$ SA & $\mathrm{NS}$ & $\mathrm{NS}$ & $\mathrm{NS}$ & $\mathrm{NS}$ & \\
\hline
\end{tabular}

Results correspond to the mean \pm standard deviation

$N S$ not significant

$* * \mathrm{P} \leq 0.01$; *** $\mathrm{P} \leq 0.001$ 
Table 5 Effects of species and sampling area on goat and sheep meat color parameters after airdrying process

\begin{tabular}{llllll}
\hline & $\mathrm{L}^{*}$ & $\mathrm{a}^{*}$ & $\mathrm{~b}^{*}$ & $\mathrm{H}$ & $\mathrm{C}$ \\
\hline Species & & & & & \\
$\quad$ Goat & $25.27 \pm 3.52$ & $7.47 \pm 4.33$ & $5.65 \pm 1.66$ & $42.28 \pm 16.53$ & $9.68 \pm 3.93$ \\
$\quad$ Sheep & $30.71 \pm 32.28$ & $4.63 \pm 2.43$ & $5.98 \pm 2.11$ & $53.85 \pm 8.44$ & $7.65 \pm 3.03$ \\
Sampling area & & & & & \\
$\quad$ Subscapularis & $30.89 \pm 25.03$ & $6.74 \pm 4.00$ & $6.43 \pm 1.80$ & $46.82 \pm 15.18$ & $9.62 \pm 3.54$ \\
$\quad$ Semimembranosus & $25.08 \pm 3.55$ & $5.36 \pm 3.96$ & $5.19 \pm 1.63$ & $49.32 \pm 15.63$ & $7.71 \pm 3.76$ \\
Effects & & & & & $*$ \\
$\quad$ Species & $*$ & $* *$ & $* * *$ & NS & $* * *$ \\
Sampling area & $*$ & $* * *$ & NS & $* * *$ & NS \\
S $\times$ SA & NS & NS & NS & NS & \\
\hline
\end{tabular}

Results correspond to the mean \pm standard deviation

NS not significant

$* \mathrm{P} \leq 0.05 ; * * \mathrm{P} \leq 0.01 ; * * * \mathrm{P} \leq 0.001$ detected in both species which is relevant for acceptability of final product. Significant differences between species were noted. With respect to sampling area, $\mathrm{a}^{*}$ and $\mathrm{C}^{*}$ parameters were found to be differently $(\mathrm{P} \leq 0.001)$ higher in subscapularis than semimembranosus, while $\mathrm{H}^{*}$ resulted higher in semimembranosus. Not significant interaction between sampling area and species were observed.

$\mathrm{L}^{*}$ (34.7) and $\mathrm{b}^{*}$ (6.5) values found in meat from Serrana breed by [6] were close to those measured here, despite in this study, double time was used for salting. With respect to the rest of color parameters, differences of 26,84 and $96 \%$ for $\mathrm{H}^{*}, \mathrm{a}^{*}$ and $\mathrm{C}^{*}$, respectively, are estimated.

The effect of air-drying process in the meat color is shown in Table 5. The most affected parameters were $a^{*}$, $\mathrm{H}^{*}$ and $\mathrm{C}^{*}$. Air-drying made meats darker, less yellow and less vivid. $L^{*}, b^{*}$ and $C^{*}$ parameters were significantly higher for sheep meat than goat; whilst $\mathrm{a}^{*}$ value was significantly lower. Significant differences were detected for $\mathrm{L}^{*}, \mathrm{a}^{*}, \mathrm{H}^{*}$ and $\mathrm{C}^{*}$ values between different types of muscle. In addition, the statistical interaction between species and sampling area was not significant in terms of color meaning that meat goat and sheep samples from subscapularis and semimembranosus muscles behave similarly with air-drying process.

\section{Conclusions}

Physical parameters $\left(\mathrm{pH}, \mathrm{a}_{\mathrm{w}}, \mathrm{WHC}\right.$ and texture) and color parameters of fresh goat and sheep meat were significantly different; WHC and texture showed the most clear variability which were mainly influenced by $\mathrm{pH}$. Sheep meat resulted to be tenderer and have better color uniformity than other species evaluated. Salting and air-drying processes altered the color parameters of meat from both species. A slight decrease in brightness $\left(\mathrm{L}^{*}\right)$, a greater decrease in the redness $\left(a^{*}\right)$ and yellowness $\left(b^{*}\right)$ and consequently in Chroma $\left(\mathrm{C}^{*}\right)$ were observed as well as an increase of Hue $\left(\mathrm{H}^{*}\right)$. Overall, meat blankets darker were obtained. The type of muscle influenced mainly $\mathrm{a}^{*}, \mathrm{H}^{*}$ and $\mathrm{C}^{*}$ values into measurements made in a same species. However, goat and sheep meat from subscapularis and semimembranosus behaved similarly with salting and airdrying process. Results of this physical evaluation showed the preparation of goat and sheep meat mantas as a good strategy to valorize meat from discarded animals, promoted the diversification of processed products from small ruminants and it could increase revenue for producers.

Acknowledgments This study was framed in the project of cooperation among Carcass and Meat Quality and Technology Laboratory of Agrarian School of Bragança, ANCRAS - Serrana Goat National Association of Breed Producers, ACOB-Bragançana Sheep National Association of Breed Producers and Bísaro Salsicharia Tradicional and financially supported by BISOVICAP.

\section{References}

1. FAO, Statistics. Agricultural production. (Food and Agriculture Organization of the United Nations, 2015), http://www.fao.org/ economic/ess/ess-publications/ess-yearbook/ess-yearbook2010/ yearbook2010-production/en/. Accessed 22 Feb 2015

2. FAO, Statistics. Consumption. (Food and Agriculture Organization of the United Nations, 2015), http://www.fao.org/economic/ ess/ess-publications/ess-yearbook/ess-yearbook2010/yearbook2010consumption/es/. Accessed 22 Feb 2015

3. S. Rodrigues, A. Teixeira, Consumers' preferences for meat of Cabrito Transmontano. Effects of sex and carcass weight. Span. J. Agric. Res. 8(4), 936-945 (2010)

4. H.C. Schönfeldt, R.T. Naudé, W. Bok, S.M. van Heerden, R. Smit, E. Boshoff, Flavour- and tenderness-related quality characteristics of goat and sheep meat. Meat Sci. 34(3), 363-379 (1993)

5. E.L. Walker, M.D. Hudson, in Species of meat animals I sheep and goats, ed. by M. Dikeman, C. Devine (Academic Press, Oxford, 2014), pp. 374-379 
6. A. Teixeira, E. Pereira, E. Rodrigues, Goat meat quality. Effects of salting, air-drying and ageing processes. Small Rumin Res. 98(1), 55-58 (2011)

7. E.C. Webb, N.H. Casey, L. Simela, Goat meat quality. Small Rumin Res. 60(1-2), 153-166 (2005)

8. E. Hierro, L. de la Hoz, J.A. Ordóñez, Headspace volatile compounds from salted and occasionally smoked dried meats (cecinas) as affected by animal species. Food Chem. 85(4), 649-657 (2004)

9. T.T. Håseth, G. Thorkelsson, M.S. Sidhu, in North European Products, ed. by F. Toldrá (Blackwell, Oxford, 2008), pp. $407-413$

10. Y.P. Gadekar, B.D. Sharma, A.K. Shinde, A.K. Verma, S.K. Mendiratta, Effect of natural antioxidants on the quality of cured, restructured goat meat product during refrigerated storage $\left(4 \pm 1{ }^{\circ} \mathrm{C}\right)$. Small Rumin Res. 119(1-3), 72-80 (2014)

11. L.H. Villalobos-Delgado, I. Caro, C. Blanco, L. Morán, N. Prieto, R. Bodas et al., Quality characteristics of a dry-cured lamb leg as affected by tumbling after dry-salting and processing time. Meat Sci. 97(1), 115-122 (2014)

12. NP-3441, Determinação do pH. Método de referência (IPQ, Lisbon, 2008)

13. AOAC, Official Methods of Analysis 15th edn. (Association of Official Analytical Chemists, Washington, DC, 1990)

14. K.O. Honikel, Reference methods for the assessment of physical characteristics of meat. Meat Sci. 49, 447-457 (1998)

15. CIE, Colorimetry, 2nd ed. Commission International de l'Eclairage (CIE Publications No. 152, Vienna, 1986)

16. G. Wu, M.M. Farouk, S. Clerens, K. Rosenvold, Effect of beef ultimate $\mathrm{pH}$ and large structural protein changes with aging on meat tenderness. Meat Sci. 98(4), 637-645 (2014)

17. A. Watanabe, C. Devine, Effect of meat ultimate $\mathrm{pH}$ on rate of titin and nebulin degradation. Meat Sci. 42(4), 407-413 (1996)
18. M.A. Paleari, V.M. Moretti, G. Beretta, T. Mentasti, C. Bersani, Cured products from different animal species. Meat Sci. 63(4), 485-489 (2003)

19. A.F. Oliveira, Short Communication: quality of ewe and goat meat cured product. An approach to provide value added to culled animals. Can. J. Anim. Sci. 94(3), 459-462 (2014)

20. L. Guerrero, P. Gou, J. Arnau, The influence of meat $\mathrm{pH}$ on mechanical and sensory textural properties of dry-cured ham. Meat Sci. 52(3), 267-273 (1999)

21. I.T. Kadim, O. Mahgoub, S. Khalaf, Effects of the transportation during hot season and electrical stimulation on meat quality characteristics of goat Longissimus dorsi muscle. Small Rumin Res. 121(1), 120-124 (2014)

22. A.R. Sen, A. Santra, S.A. Karim, Carcass yield, composition and meat quality attributes of sheep and goat under semiarid conditions. Meat Sci. 66(4), 757-763 (2004)

23. P.J. Heinze, M.C. Smith, R.T. Naudé, R.L. Boccard, Influence of breed and age on collagen content and solubility of some ovine and goat muscles. Ghent, Belgium, 24-29 August 1986

24. G. Monin, V. Santé-Lhoutellier, in Conversion of Muscle to Meat I Color and Texture Deviations, ed. by M. Dikeman, C. Devine (Academic Press, Oxford, 2014), pp. 339-345

25. D.A. Ledward, Post-slaughter influences on the formation of metyyoglobin in beef muscles. Meat Sci. 15(3), 149-171 (1985)

26. S.K. Devatkal, B.M. Naveena, Effect of salt, kinnow and pomegranate fruit by-product powders on color and oxidative stability of raw ground goat meat during refrigerated storage. Meat Sci. 85(2), 306-311 (2010)

27. J.E. Hayes, T.A. Kenny, P. Ward, J.P. Kerry, Development of a modified dry curing process for beef. Meat Sci. 77(3), 314-323 (2007) 